\title{
Pembentukan Perilaku Tanggung Jawab Lingkungan melalui Keikutsertaan Siswa SMA dalam Kegiatan Ekstrakurikuler Kelompok Pecinta Alam
}

\author{
Ade Suryanda $^{1)}$, Mieke Miarsyah ${ }^{2)}$, Dian Septiani ${ }^{3)}$ \\ ${ }^{1}$ Program Studi Pendidikan Biologi, FMIPA, Universitas Negeri Jakarta \\ email: asuryanda@unj.ac.id \\ ${ }^{2}$ Program Studi Magister Pendidikan Biologi, FMIPA, Universitas Negeri Jakarta \\ email:mmiarsyah@unj.ac.id \\ ${ }^{3}$ Program Studi Pendidikan Biologi, FMIPA, Universitas Negeri Jakarta \\ email: diannseptiani@gmail.com
}

APA Citation: Suryanda, A., Miarsyah, M., \& Septiani, D. (2020). Pembentukan Perilaku Tanggung Jawab Lingkungan melalui Keikutsertaan Siswa SMA dalam Kegiatan Ekstrakurikuler Kelompok Pecinta Alam. Quagga: Jurnal Pendidikan dan Biologi, 12(2), 94-103. doi: 10.25134/quagga.v12i2.2764.

Received: 26-04-2020

Accepted: 04-06-2020

Published: 01-07-2020

\begin{abstract}
Abstrak: Perilaku tanggung jawab lingkungan merupakan suatu tindakan yang berkontribusi dalam kelestarian lingkungan. Perilaku tanggung jawab lingkungan dapat diperoleh melalui adanya suatu organisasi yaitu Kelompok Pecinta Alam. Tujuan penelitian ini adalah untuk mengetahui pengaruh keikutsertaan siswa dalam Kelompok Pecinta Alam terhadap perilaku tanggung jawab lingkungan. Penelitian ini dilakukan di SMAN 5 Jakarta, SMAN 31 Jakarta, SMAN 35 Jakarta, SMAN 59 Jakarta dan SMAN 81 Jakarta pada tahun 2019. Metode yang digunakan pada penelitian ini adalah metode Ex Post Facto. Sampel yang digunakan pada penelitian ini berjumlah 130 sampel. Pengambilan data dilakukan dengan menggunakan kuisioner perilaku tanggung jawab lingkungan. Uji hipotesis menggunakan uji t. Hasil penelitian menunjukkan bahwa nilai rata-rata perilaku tanggung jawab lingkungan pada siswa kelompok pecinta alam lebih tinggi dibandingkan siswa yang tidak mengikuti kelompok pecinta alam. Berdasarkan hasil tersebut dapat disimpulkan bahwa terdapat pengaruh keikutsertaan siswa dalam kelompok pecinta alam terhadap perilaku tanggung jawab lingkungan.
\end{abstract}

Kata kunci: pecinta alam; perilaku; siswa; tanggung jawab lingkungan.

Abstract: Environmental responsible behaviour is an action that contribute to environmental sustainability. Environmental responsible behavior can be obtained through the existence of an organization that is nature lover community. The research aims to investigate the effect of participation of students in nature lover community toward environmental responsible behavior and conducted in 2019 at SMAN 5 Jakarta, SMAN 31 Jakarta, SMAN 35 Jakarta, SMAN 59 Jakarta, and SMAN 81 Jakarta. The method used in this research is Ex Post Facto. The sample used in this study amounts to 130 samples. Data retrieval is performed using questionnaire environmental responsible behavior. Hypothesis tests using t test. The final results of this research showed the average score of environmental responsible behavior students in nature lover community is higher than the students who do not join nature lover community. Based on this results, it is conclude that there is an effect of participation of students in a nature lover community toward environmental responsible behavior.

Keywords: behaviour; environmental knowledge; nature lover; student

\section{PENDAHULUAN}

Manusia dan alam adalah dua hal yang tidak dapat dipisahkan. Manusia merupakan bagian integral dari alam. Manusia memenuhi kebutuhan hidupnya dengan memanfaatkan sesuatu yang ada di alam. Alam dapat terjaga keberlangsungannya dengan sikap dan kesadaran manusia yang menghuninya, Manusia dengan alam menjadi satu kesatuan utuh yang saling terkait dan bersifat fungsional.

Kebutuhan manusia yang terus berkembang dan harus dipenuhi membuat manusia memanfaatkan alam dengan cara mengeskploitasi sumber daya alam secara berlebihan (Rusdina, 2015). Pemanfaatan sumber daya alam secara berlebihan oleh manusia untuk memenuhi 
kebutuhan hidupnya ataupun aktivitas manusia yang tidak bertanggung, seperti penebangan hutan dan alih fungsi hutan, pertambangan maupun aktivitas yang menyebabkan terjadinya pencemaran udara, air dan tanah menjadi faktor penyebab terjadinya kerusakan lingkungan (Ashar, 2018; Wulandari, 2016). Manusia juga menyebabkan jumlah sampah meningkat setiap harinya. Volume sampah yang dihasilkan per orang rata-rata sekitar 0,5 kg/kapita/hari (Sudradjat, 2007; Kahfi, 2017) Sampah menjadi permasalahan bagi lingkungan dan manusia itu sendiri jika tidak dikelola dengan baik.

Menjaga lingkungan merupakan tanggung jawab bersama seluruh masyarakat. Idealnya sebagai bagian yang integral dari alam, manusia dapat arif dalam berinteraksi dengan lingkungannya. Mengurangi penggunaan sampah plastik, menggunakan alat dan bahan yang ramah terhadap lingkungan, serta menghemat energi merupakan wujud dari tanggung jawab manusia terhadap lingkungan.

Pada kenyataannya, saat ini kerusakan lingkungan diindikasikan semakin meningkat, atau kualitas lingkungan semakin menurun (Mulyana, 2009; Rusdina, 2015; D.V. Sigit et al., 2019; Wulandari, 2016) Kondisi ini berkaitan dengan belum semua masyarakat peduli dengan kualitas lingkungan dan turut serta menjaga kelestarian lingkungan (Diana Vivanti Sigit, Azrai, Suryanda, \& Ichsan, 2020; Wulandari, 2016) Banyak ahli yang menyatakan, salah satu penyebab rendahnya kesadaran terhadap kelestarian lingkungan adalah belum diaplikasikannya pengetahuan lingkungan oleh masyarakat, bahkan banyak masyarakat yang belum memiliki pengetahuan lingkungan dan pelestariannya (Ardianti, Wanabuliandari, \& Rahardjo, 2017; Ernawati, Azrai, \& Wibowo, 2016; Nurhayati, Sukandar, \& Suryanda, 2014; Suryanda, Azrai, \& Wari, 2018; Suryanda, Komala, \& Rahmawati, 2017; Zelezny \& Schultz, 2000; Zsóka, Szerényi, Széchy, \& Kocsis, 2013). Pengetahuan lingkungan merupakan istilah yang digunakan untuk menyebutkan pengetahuan dan kepedulian tentang masalah lingkungan serta mampu mengajukan solusi dan mengimplementasikannya (Zsóka et al., 2013). Pengetahuan itu sendiri merupakan kemampuan kognitif manusia yang sangat penting yang dapat membentuk tindakan manusia melalui pengalamannya (Anderson et al., 2001; Gusti, Isyandi, Bahri, \& Afandi, 2015), Tidak tertanamnya karakter peduli dan tanggung jawab lingkungan dengan baik adalah hal yang menyebabkan terjadinya kerusakan lingkungan hidup (Ardianti et al., 2017).

Salah satu cara untuk mengatasi kerusakan lingkungan, yaitu dengan mengubah perilaku manusia (Mulyana, 2009). Hal ini didasari atas pemikiran bahwa perilaku yang didasari pengetahuan akan jauh lebih baik daripada perilaku yang tidak didasari pengetahuan (Mulyana, 2009; Rusdina, 2015). Perilaku yang perlu dibina dan dikembangkan adalah perilaku peduli dan tanggung jawab lingkungan. Perilaku tanggung jawab lingkungan didefinisikan sebagai suatu tindakan yang berasal dari motivasi seseorang dalam bertujuan untuk mencegah kerusakan lingkungan atau yang diarahkan dalam perbaikan lingkungan (Hines, Hungerford, \& Tomera, 1987; Kaplan, 2000; Zelezny \& Schultz, 2000). Perilaku tanggung jawab lingkungan ini adalah tindakan apapun yang mempunyai tujuan untuk berkontribusi dalam memecahkan masalah lingkungan.

Perilaku tanggung jawab lingkungan yang masih kurang ini harus ditanggapi dengan serius. Salah satu langkahnya adalah dengan mengubah perilaku melalui jalur pendidikan (Hudha, Husamah, \& Rahardjanto, 2019; Keraf, 2010). Pendidikan dikatakan sebagai sarana yang paling tepat didalam membangkitkan kesadaran dan perubahan perilaku manusia terhadap lingkungan hidup (Hudha et al., 2019; Keraf, 2010; Rusdina, 2015) Pendidikan lingkungan hidup dapat dilaksanakan melalui adanya pembinaan kesiswaan disekolah.

Salah satu upaya untuk meningkatkan perilaku tanggung jawab lingkungan siswa di sekolah yang didasari dengan pengetahuan lingkungan dapat melalui pembinaan kesiswaan pada kegiatan ekstrakurikuler kelompok pecinta alam (KPA). Pembinaan kesiswaan melalui ekstrakurikuler tidak hanya mengembangkan kebutuhan, potensi, bakat dan minat saja melainkan dapat mengubah perilaku siswa menjadi lebih baik (Aqib \& Sujak, 2011). Kelompok pecinta alam adalah suatu kelompok yang anggotanya memiliki kecintaan terhadap alam dan secara langsung bergerak dalam bidang lingkungan untuk membantu dalam menjaga kelestarian lingkungan (Pasaribu, 2017).

Tujuan ekstrakurikuler tersebut, yaitu membentuk siswa memiliki rasa kecintaannya 
terhadap alam sehingga dapat menambah pengetahuan lingkungan dan memiliki perilaku tanggung jawab lingkungan (Pasaribu, 2017; Putra \& Sari, 2017; Rifki \& Listyaningsih, 2017; Sukmana, 2011)). Berdasarkan hal tersebut dapat diketahui bahwa siswa yang mengikuti kegiatan ekstrakurikuler kelompok pecinta alam (KPA) akan diarahkan untuk ikut serta menjaga kelestarian alam. Hal tersebut diwujudkan melalui berbagai aktivitas pendalaman materi dan praktik yang relevan dengan tujuan ekstrakurikuler kelompok pecinta alam. Beberapa kegiatan yang umum dilakukan oleh siswa peserta ekstrakurikuler pecinta alam adalah bakti sosial, kebersihan lingkungan, reboisasi/penghijauan, perlombaan, kemah, konservasi, pendakian gunung, lintas alam, penelusuran gua, menyelam, pameran, ekspedisi, diskusi, seminar, penelitian, penyuluhan, kerjasama dengan organisasi cinta alam lainnya atau organisasi lain dan aktivitas kegiatan lain yang berkaitan dengan kegiatan cinta alam (Direktorat Jenderal Perlindungan Hutan dan Konservasi Alam, 2006). Melalui keterlibatannya dalam kegiatankegiatan yang dilakukan pada kelompok pecinta alam ini semestinya berkorelasi positif dengan terbentuknya karakter siswa yang peduli dan aktif terlibat dalam perbaikan dan kelestarian lingkungan.

Idealnya, siswa yang mengikuti kegiatan ekstrakurikuler kelompok pecinta alam semestinya memiliki kesadaran untuk menjaga serta memelihara lingkungan di sekitarnya (Rifki \& Listyaningsih, 2017). Berdasarkan uraian tersebut, perlu kiranya digali informasi tentang pembentukan karakter dan tanggung jawab lingkungan siswa yang aktif dalam kelompok ekstrakurikuler pecinta alam. Oleh karena itu, dalam kajian ini dilakukan identifikasi karakter peduli lingkungan siswa yang mengikuti ekstrakurikuler pecinta alam, yang dibandingkan dengan siswa yang tidak mengikutinya. Informasi ini penting untuk mengetahui tingkat keberhasilan eksktrakurikuler pecinta alam dalam membentuk karakter peduli lingkungan siswa serta menentukan rancangan program tidak lanjutnya, baik untuk program ekstrakurikuler itu sendiri, maupun siswa lainnya.

\section{METODOLOGI PENELITIAN}

Penelitian ini dilakukan di SMA Negeri 5 Jakarta, SMA Negeri 31 Jakarta, SMAN 35 Jakarta,
SMA Negeri 59 Jakarta dan SMA Negeri 81 Jakarta tahun 2019. Sekolah-sekolah tersebut dipilih, karena KPA di sekolah tersebut aktif dengan beberapa program. Kelompok Pecinta Alam Edelweiss SMA Negeri 5 Jakarta terdapat program pergi ke pulau, pendakian gunung, kebersihan lingkungan dan perayaan Hari Ulang Tahun (HUT) kelompok pecinta alam. Tigmapala SMA Negeri 35 Jakarta memiliki program Pengenalan Gunung Hutan (PGH), pelantikan, pengembaraan, pengukuhan dan polisi kebersihan. Carvedium SMA Negeri 81 Jakarta terdapat program pengenalan alam, latihan dasar, vertical garden, dan galavant, Grapala SMA Negeri 31 Jakarta terdapat program kebersihan lingkungan, latihan dasar, seminar, dan penanggulangan bencana alam. Spalix di SMA Negeri 59 Jakarta memiliki program pengenalan alam, let's clean, dan latihan dasar.

Penelitian yang digunakan adalah penelitian kuantitatif dengan metode ex-post Facto, dengan desain penelitian sebagai berikut:

Tabel 1. Desain Penelitian

\begin{tabular}{ccc}
\hline $\begin{array}{c}\text { Variabel } \\
\text { Bebas (X) }\end{array}$ & $\mathrm{X}_{1}$ & $\mathrm{X}_{2}$ \\
\hline Variabel & & $\mathrm{Y}$ \\
terikat (Y) & & \\
\hline
\end{tabular}

Keterangan:

X1: Siswa yang mengikuti kelompok pecinta alam

$\mathrm{X}$ 2: Siswa yang tidak mengikuti kelompok pecinta alam

Y2: Skor perilaku tanggung jawab lingkungan

Lokasi dalam penelitian ini ditentukan secara purposive sampling, berdasarkan hasil survey awal diketahui bahwa kelima sekolah tersebut memiliki kelompok pecinta alam yang aktif.

Setelah dilakukan survey maka didapatkan jumlah siswa yang mengikuti kelompok pecinta alam dari SMA Negeri 5 Jakarta sebanyak 6 siswa, SMA Negeri 31 Jakarta sebanyak 11 siswa, SMA Negeri 35 Jakarta sebanyak 26 siswa, SMA Negeri 59 Jakarta sebanyak 12 siswa dan SMA Negeri 81 Jakarta sebanyak 22 siswa. Oleh karena itu, didapatkan jumlah populasi sebanyak 77. Dalam menentukan jumlah sampel yang diperlukan maka menggunakan rumus Taro Yamane dan tingkat kesalahan sebesar 5\% sehingga diperoleh jumlah sampel sebanyak 65, yang diambil secara simple 
random sampling, dengan ketentuan seperti pada Tabel 2.

Tabel 2. Proporsi Sampel masing-masing Sekolah

\begin{tabular}{lcc}
\hline Nama Sekolah & $\begin{array}{c}\text { Jumlah } \\
\text { Anggota }\end{array}$ & $\begin{array}{c}\text { Jumlah } \\
\text { Sampel }\end{array}$ \\
\hline $\begin{array}{l}\text { SMA Negeri 5 } \\
\text { Jakarta }\end{array}$ & 6 & 5 \\
\hline $\begin{array}{l}\text { SMA Negeri 31 } \\
\text { Jakarta }\end{array}$ & 11 & 9 \\
\hline $\begin{array}{l}\text { SMA Negeri 35 } \\
\text { Jakarta }\end{array}$ & 26 & 22 \\
\hline $\begin{array}{l}\text { SMA Negeri 59 } \\
\text { Jakarta }\end{array}$ & 12 & 10 \\
\hline $\begin{array}{l}\text { SMA Negeri 81 } \\
\text { Jakarta }\end{array}$ & 22 & 19 \\
\hline \multicolumn{1}{c}{ Jumlah } & 77 & 65 \\
\hline
\end{tabular}

Siswa dikategorikan ikut serta dalam kelompok pecinta alam adalah siswa aktif yang mengikuti latihan dan kegiatan secara rutin yang diselenggarakan organisasi tersebut. Siswa yang dikategorikan tidak ikut serta dalam kelompok pecinta alam apabila siswa tidak tergabung dalam kelompok pecinta alam. Kelompok ini diambil juga sebagai sampel dengan simple random sampling sebanyak 65 siswa. Jumlah sampel kelompok ini, untuk masing-masing sekolah, mengikuti jumlah siswa yang aktif di kelompok pecinta alam, tanpa memperhatikan asal peminatan.

Data penelitian ini diperoleh melalui kuesioner perilaku tanggung jawab lingkungan yang diberikan kepada siswa kelompok pecinta alam dan non pecinta alam, yang mencakup beberapa dimensi seperti pada Tabel 3 .

Tabel 3. Instrumen Perilaku Tanggung Jawab Lingkungan

\begin{tabular}{|c|c|c|c|c|}
\hline No & & Dimensi & Indikator & $\Sigma$ \\
\hline \multirow{2}{*}{1} & \multirow{5}{*}{ 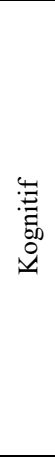 } & \multirow{2}{*}{$\begin{array}{l}\text { Pengetahuan } \\
\text { Isu-Isu } \\
\text { (Knowledge of } \\
\text { Issues) }\end{array}$} & $\begin{array}{c}\text { Menemukan } \\
\text { masalah yang } \\
\text { terjadi di } \\
\text { lingkungan }\end{array}$ & 6 \\
\hline & & & $\begin{array}{l}\text { Mengenali } \\
\text { penyebab } \\
\text { rusaknya } \\
\text { lingkungan } \\
\end{array}$ & 4 \\
\hline \multirow{3}{*}{2} & & \multirow{3}{*}{$\begin{array}{l}\text { Pengetahuan } \\
\text { tentang Strategi } \\
\text { (Knowledge of } \\
\text { Strategies) }\end{array}$} & $\begin{array}{l}\text { Pengetahuan } \\
\text { reduce }\end{array}$ & 4 \\
\hline & & & $\begin{array}{c}\text { Pengetahuan } \\
\text { reuse }\end{array}$ & 4 \\
\hline & & & $\begin{array}{l}\text { Pengetahuan } \\
\text { recycle }\end{array}$ & 4 \\
\hline
\end{tabular}

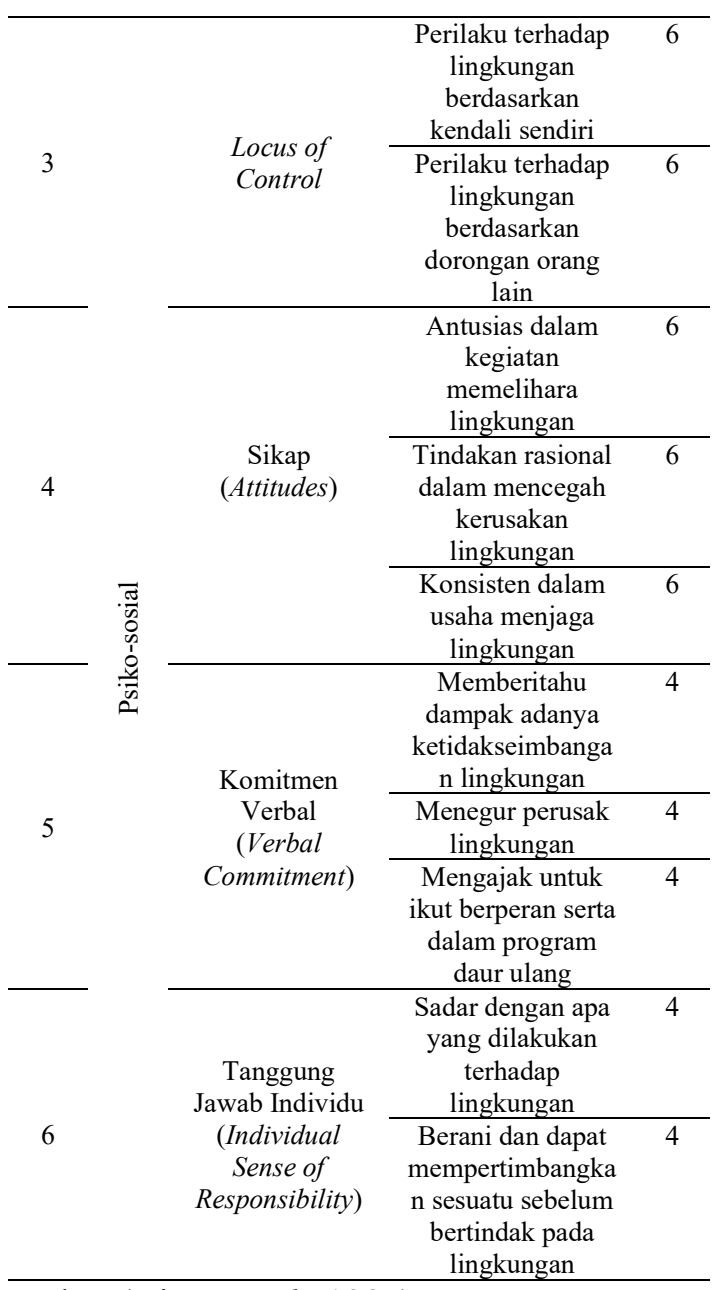

Sumber (Hines et al., 1987)

Data yang didapatkan dari instrumen penelitian akan dianalisis dengan menggunakan uji t pada taraf signifikansi $\alpha=0,05$ untuk mengetahui apakah terdapat pengaruh antara keikutsertaan siswa dalam kelompok pecinta alam terhadap perilaku tanggung jawab lingkungan. Pengujian dibantu software SPSS versi 24.0.

Hasil analisis nilai perilaku tanggung jawab lingkungan dikelompokkan menjadi lima kategori, yaitu sangat baik, baik, cukup baik, buruk dan sangat buruk dengan kriteria sebagai berikut:

Tabel 4. Kriteria perilaku tanggung jawab lingkungan

\begin{tabular}{cc}
\hline Kriteria & Rentang Nilai (\%) \\
\hline Sangat Baik & $81-100$ \\
\hline Baik & $61-80$ \\
\hline Cukup Baik & $41-60$ \\
\hline
\end{tabular}


Quagga: Jurnal Pendidikan dan Biologi

Volume 12, Nomor 2, Juli 2020, pp.94-103

\begin{tabular}{cc}
\hline Buruk & $21-40$ \\
\hline Sangat Buruk & $0-20$ \\
\hline
\end{tabular}

HASIL DAN PEMBAHASAN

HASIL

a. Interpretasi Perilaku Tanggung Jawab Lingkungan Siswa Berdasarkan Keikutsertaan dalam Kelompok Pecinta Alam

Berdasarkan hasil analisis terhadap respons kuesioner dapat diketahui data dari siswa pecinta alam dan yang tidak mengikuti, seperti terlihat pada Gambar 1. Siswa anggota kelompok pecinta alam menunjukkan interpretasi dari mulai sangat baik, baik dan cukup baik. Adapun siswa bukan anggota kelompok pecinta alam menunjukkan interpretasi dari mulai sangat baik, baik, cukup baik, dan rendah.

Berdasarkan hasil penelitian dapat diketahui bahwa siswa anggota kelompok pecinta alam memiliki nilai perilaku tanggung jawab lingkungan dengan interpretasi sangat baik sebanyak $12 \%$, baik sebanyak $75 \%$, dan cukup baik sebanyak $12 \%$. Pada siswa bukan anggota kelompok pecinta alam memiliki nilai perilaku tanggung jawab lingkungan dengan interpretasi sangat baik sebanyak $2 \%$, baik sebanyak $48 \%$, cukup baik sebanyak $49 \%$ dan buruk sebanyak $2 \%$.

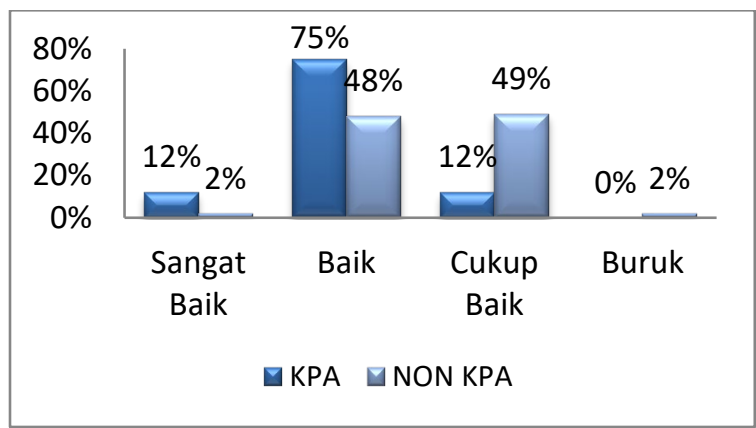

Gambar 1. Interpretasi Perilaku Tanggung Jawab Lingkungan

\section{b. Perbandingan Nilai Rata-rata Perilaku Tanggung Jawab Lingkungan Siswa Berdasarkan Keikutsertaan dalam Kelompok Pecinta Alam}

Berdasarkan hasil perhitungan diperoleh nilai rata-rata hasil pengukuran perilaku tanggung jawab lingkungan siswa anggota kelompok pecinta alam lebih tinggi dibandingkan siswa bukan anggota
p-ISSN 1907-3089, e-ISSN2651-5869

https://journal.uniku.ac.id/index.php/quagga kelompok pecinta alam. Siswa anggota kelompok pecinta alam memiliki nilai rata-rata 70,55 dan siswa yang bukan anggota kelompok pecinta alam memiliki nilai rata-rata 60,50 .

\section{c. Perbedaan Rata-rata Skor Perilaku Tanggung Jawab Lingkungan Berdasarkan Dimensi}

Pada perolehan skor perilaku tanggung jawab lingkungan disusun melalui beberapa dimensi. Dimensi pada perilaku tanggung jawab lingkungan tersebut terdiri atas enam dimensi. Hasil penelitian menunjukkan bahwa siswa anggota kelompok pecinta alam lebih tinggi rata-rata skor perilaku tanggung jawab lingkungan pada setiap dimensi dibandingkan siswa bukan anggota kelompok pecinta alam.

Berdasarkan hasil perhitungan, jumlah skor tertinggi pada variabel kognitif siswa anggota elompok pecinta alam terdapat pada dimensi pengetahuan isu-isu atau knowledge of issues (KOI) dengan jumlah skor 232 sedangkan pada skor terendah terdapat pada dimensi pengetahuan strategi atau knowledge of strategies (KOS) dengan jumlah skor 199. Selanjutnya jumlah skor tertinggi pada variabel psiko-sosial siswa anggota kelompok pecinta alam terdapat pada dimensi tanggung jawab individu atau individual sense of responsibility (ISOR) dengan skor 274 sedangkan pada skor terendah terdapat pada dimensi locus of control (LOC) dengan jumlah skor 212.

Selanjutnya jumlah skor tertinggi pada variabel kognitif siswa bukan anggota kelompok pecinta alam juga terdapat pada dimensi pengetahuan isu-isu atau knowledge of issues (KOI) dengan jumlah skor 199 sedangkan pada skor terendah terdapat pada dimensi pengetahuan strategi atau knowledge of strategies (KOS) dengan jumlah skor188. Perbedaan skor pengetahuan lingkungan siswa anggota kelompok pecinta alam dan siswa bukan anggota kelompok pecinta alam berdasarkan indikatornya dapat dilihat pada gambar. Selain itu, jumlah skor tertinggi pada variabel psiko-sosial siswa bukan anggota kelompok pecinta alam terdapat pada dimensi tanggung jawab individu atau individual sense of responsibility (ISOR) dengan skor 225 sedangkan pada skor terendah terdapat pada dimensi locus of control (LOC) dengan jumlah skor 175. 
Quagga: Jurnal Pendidikan dan Biologi

Volume 12, Nomor 2, Juli 2020, pp.94-103

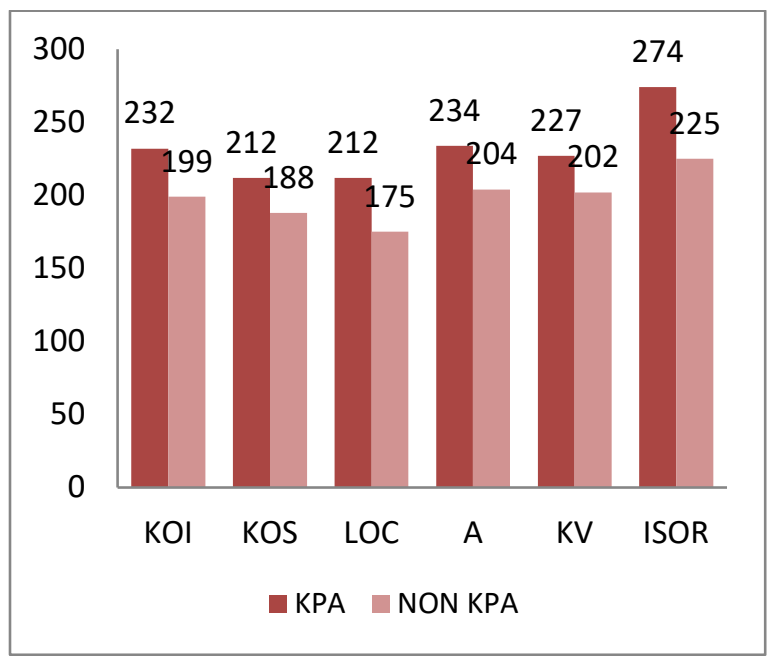

Gambar 2. Perbedaan Rata-rata Skor Perilaku Tanggung Jawab Lingkungan

\section{d. Pengujian Analisis Data}

Hasil Pengujian hipotesis dengan menggunakan software SPSS 24.0, diperoleh nilai signifikansi pada skor perilaku tanggung jawab lingkungan sebesar 0,000. Hal tersebut menunjukkan bahwa nilai signifikansi $<0,05$ sehingga rata-rata skor perilaku tanggung jawab lingkungan siswa yang mengikuti kelompok pecinta alam tidak sama dengan rata-rata skor perilaku tanggung jawab lingkungan siswa yang tidak mengikuti kelompok pecinta alam. Hal ini disimpulkan bahwa terdapat pengaruh keikutsertaan siswa dalam kelompok pecinta alam terhadap perilaku tanggung jawab lingkungan.

\section{PEMBAHASAN}

Berdasarkan hasil uji hipotesis dapat diketahui bahwa terdapat pengaruh keikutsertaan siswa dalam kelompok pecinta alam terhadap perilaku tanggung jawab lingkungan. Selanjutnya berdasarkan hasil perhitungan rata-rata skor perilaku tanggung jawab lingkungan juga dapat diketahui bahwa siswa yang mengikuti kelompok pecinta alam lebih tinggi dibandingkan siswa yang tidak mengikuti kelompok pecinta alam.

Kegiatan ekstrakurikuler merupakan kegiatan yang memiliki tujuan untuk memperdalam dan memperluas pengetahuan, membentuk nilai-nilai karakter, serta menyalurkan bakat dan minat siswa begitupun juga dengan kelompok pecinta alam. Kelompok pecinta alam ini merupakan salah satu wadah untuk siswa yang memiliki minat dalam mencintai alam. Ekstrakurikuler kelompok pecinta alam ini menyelenggarakan kegiatan-kegiatan yang berkaitan dengan alam. Siswa diarahkan untuk ikut menjaga dan melestarikan lingkungan melalui kegiatan tersebut. Kegiatan-kegiatan tersebut meliputi materi-materi dan praktek-praktek yang dilaksanakan dalam menunjukkan rasa cinta siswa terhadap alam.

Ekstrakurikuler kelompok pecinta alam menyelenggarakan kegiatan-kegiatan yang berkaitan dengan alam sehingga dapat mempengaruhi perilaku siswa sebagai anggota pada lingkungan.

Tingginya tingkat perilaku tanggung jawab lingkungan pada siswa anggota kelompok pecinta alam disebabkan karena dalam kelompok pecinta alam terdapat proses belajar dan pengalaman siswa dalam bidang lingkungan. Belajar dan pengalaman merupakan suatu proses yang dapat mengubah sikap, tingkah laku, dan pengetahuan (Thobroni \& Mustofa, 2011).

Kegiatan-kegiatan dalam kelompok pecinta alam berupa diskusi, seminar, konservasi, pembinaan keanggotaan, pendakian gunung dan kegiatan sosial lainnya ini akan menjadi proses belajar dan pengalaman pada siswa kelompok pecinta alam (Ardahan, 2012; Mardianto, Koentjoro, \& Purnamaningsih, 2000; Saputra, Febriana, \& Akbar, 2017). Proses belajar inilah yang nantinya akan meningkatkan pengetahuan yang lebih di bidang lingkungan pada anggota kelompok pecinta alam. Selain itu bergabung dalam kelompok pecinta alam maka akan menumbuhkan sikap positif karena dilatih dalam bersikap tanggung jawab sehingga melahirkan sifat cinta terhadap alam. Sifat cinta terhadap alam ini membuat kelompok pecinta alam akan ikut menjaga dan melestarikan alam. Oleh karena itu bergabung dalam kelompok pecinta alam juga dapat meningkatkan perilaku tanggung jawab lingkungan anggota kelompok pecinta alam.

Sebagai anggota dari kelompok pecinta alam maka harus memiliki konsep diri terkait moral dan mematuhi aturan sesuai dengan kode etik pecinta alam (Putra \& Sari, 2017; Sukmana, 2011). Pada kode etik kelompok pecinta alam terdapat moral dan aturan untuk ikut menjaga dan melestarikan alam. Melalui kode etik tersebut maka setiap anggota kelompok pecinta alam memiliki kewajiban untuk menjaga dan melestarikan alam 
sehingga dapat mempengaruhi perilaku tanggung jawab terhadap lingkungan siswa kelompok pecinta alam.

Siswa yang mengikuti kelompok pecinta alam ini dituntut untuk aktif dalam berbagai program kerja yang dibentuk. Hal tersebut juga dapat dilihat pada kelompok pecinta alam pada Edelweiss di SMA Negeri 5 Jakarta, Tigmapala di SMA Negeri 35 Jakarta, Carvedium di SMA Negeri 81 Jakarta, Grapala SMA Negeri 31 Jakarta, dan Spalix di SMA Negeri 59 Jakarta. Pada kelompok pecinta alam Edelweiss terdapat program pergi ke pulau, pendakian gunung, kebersihan lingkungan dan perayaan Hari Ulang Tahun (HUT) kelompok pecinta alam. Pada kelompok pecinta alam Tigmapala terdapat program Pengenalan Gunung Hutan (PGH), pelantikan, pengembaraan, pengukuhan dan polisi kebersihan. Pada kelompok pecinta alam Carvedium terdapat program pengenalan alam, latihan dasar, vertical garden, dan galavant. Pada kelompok pecinta alam Grapala terdapat program kebersihan lingkungan, latihan dasar, seminar, dan penanggulangan bencana alam. Selanjutnya pada kelompok pecinta alam Spalix terdapat program pengenalan alam, let's clean, dan latihan dasar.

Adanya beberapa program kerja yang dibentuk tersebut mendorong siswa untuk dapat menambah pengetahuan dan pengalaman siswa. Siswa juga dapat diajarkan untuk dapat memiliki perilaku tanggung jawab lingkungannya. Tidak hanya di lingkungan sekolah saja tetapi juga pada lingkungan diluar sekolah. Pada lingkungan sekolahnya, siswa kelompok pecinta alam ini membantu dalam program kebersihan sekolah mulai dari membersihkan lingkungan sekolah yang kotor dengan sampah serta merawat taman sekolah dengan menyiram tanaman yang ada di taman sekolah serta membuang daun-daun kering yang berserakan ditaman. Selain itu, pada lingkungan di luar sekolahnya juga terdapat kegiatan kebersihan lingkungan misalnya saja pada saat pendakian gunung. Jadi saat pendakian gunung siswa tidak hanya mendaki gunung saja tetapi juga mengambil sampah yang berserakan di sekitar jalur pendakian. Melalui kegiatan tersebut siswa telah dibentuk perilaku tanggung jawabnya terhadap lingkungan.

Skor rata-rata perilaku tanggung jawab lingkungan terdapat perbedaan yang cukup jauh antara siswa anggota kelompok pecinta alam dan siswa bukan anggota kelompok pecinta alam. Hal ini disebabkan karena siswa bukan anggota kelompok pecinta alam belum memiliki kesadaran penuh untuk ikut menjaga dan melestarikan lingkungan. Sedangkan pada siswa anggota kelompok pecinta alam di tuntut untuk ikut serta dalam program kelestarian lingkungan.

Selanjutnya hasil interpretasi pada perilaku tanggung jawab lingkungan juga menunjukkan terdapat perbedaan antara siswa kelompok pecinta alam dan siswa bukan anggota pecinta alam. Banyaknya interpretasi sangat tinggi pada siswa kelompok pecinta alam menunjukkan bahwa siswa kelompok pecinta alam memiliki perilaku tanggung jawab yang lebih tinggi dibandingkan dengan siswa bukan anggota kelompok pecinta alam. Hal ini dikarenakan terdapat pemberian pengetahuan dan pemahaman tentang lingkungan sebagai sumber kehidupan yang harus dijaga kelestariannya kepada siswa anggota kelompok pecinta alam. Pemahaman tersebut berupa penanaman kesadaran pada setiap siswa anggota kelompok pecinta alam. Penanaman kesadaran yang dimaksud berkaitan dengan kewajiban dan tanggung jawab manusia untuk melestarikan lingkungan sehingga manusia tidak hanya mengambil dan memanfaatkan lingkungan untuk menunjang kebutuhan hidup saja tetapi berkewajiban dan bertanggung jawab untukmenjaga dan melestarikan lingkungan (Rifki \& Listyaningsih, 2017).

Skor pada dimensi perilaku tanggung jawab lingkungan dalam variabel kognitif paling tinggi adalah terdapat pada dimensi pengetahuan isu-isu (knowledge of issues) yaitu dengan 232 pada siswa anggota kelompok pecinta alam dan skor 199 pada siswa bukan anggota kelompok pecinta alam. Selanjutnya dalam variabel psiko-sosial paling tinggi yaitu terdapat pada dimensi tanggung jawab individu (individual sense of responsibility) dengan skor 274 pada siswa anggota kelompok pecinta alam dan skor 225 pada siswa bukan anggota kelompok pecinta alam.

Perilaku tanggung jawab lingkungan pada siswa kelompok pecinta alam yang tinggi tersebut muncul dari pengetahuan mengenai isu-isu lingkungan yang tinggi sehingga timbul kesadaran akan pentingnya menjaga lingkungan. Kesadaran merupakan salah satu aspek dari tanggung jawab individu. Oleh karena itu pada variabel psiko-sosial dimensi tanggung jawab merupakan dimensi yang 
Quagga: Jurnal Pendidikan dan Biologi

Volume 12, Nomor 2, Juli 2020, pp.94-103

memperoleh skor tertinggi. Kesadaran seseorang akan lingkungan akan bergantung pada pengetahuan ekologinya dan kesadaran itulah yang akan menentukan tanggung jawab seseorang sehingga menyebabkan seseorang berkewajiban untuk dapat bertindak terhadap lingkungan (Kaiser, Hübner, \& Bogner, 2005).

\section{SIMPULAN}

Berdasarkan hasil penelitian dapat disimpulkan bahwa terdapat pengaruh keikutsertaan siswa dalam kelompok pecinta alam terhadap perilaku tanggung jawab lingkungan. Keikutsertaan siswa dalam kelompok pecinta alam memberikan dampak positif terhadap dan perilaku tanggung jawab lingkungan. Siswa dapat menambah pengetahuan dan pengalaman melalui kegiatan pecinta alam sehingga dapat menumbuhkan rasa cinta alam. Oleh karena itu perlu dilakukan pengoptimalan peran siswa terutama pada siswa yang ikut serta dalam kelompok pecinta alam dalam mencegah terjadinya kerusakan lingkungan. Hal-hal yang dapat diprogramkan antara lain berupa bakti sosial, reboisasi/penghijauan, kegiatan bersih pantai/sungai/lingkungan, pendakian gunung, penelitian, penyuluhan, kerjasama dengan organisasi cinta alam lainnya atau organisasi lain dan aktivitas kegiatan lain yang berkaitan dengan kegiatan cinta alam. Kegiatan-kegiatan tersebut sangat disarankan melibatkan semua siswa, walau bukan anggota pecinta alam, dalam rangka penanaman perilaku tanggung jawab lingkungan.

\section{UCAPAN TERIMA KASIH}

Penulis mengucapkan terima kasih kepada Pimpinan, Siswa dan Anggota Kelompok Pecinta Alam SMAN 5 Jakarta, SMAN 31 Jakarta, SMAN 35 Jakarta, SMAN 59 Jakarta dan SMAN 81 Jakarta yang telah memberikan izin pengambilan data dan meluangkan waktunya untuk mengisi lembaran instrumen penelitian.

\section{REFERENSI}

Anderson, L. W., Krathwohl, D. R., Airasian, P. W., Cruikshank, K. A., Mayer, R. E., Pintrich, P. R., ... Wittrock, M. C. (2001). A taxonomy for learning, teaching, and assessing: a revision of Bloom 's taxonomy of educational objetives. New York: Addison Wesley Longman.
p-ISSN 1907-3089, e-ISSN2651-5869

https://journal.uniku.ac.id/index.php/quagga
Aqib, Z., \& Sujak. (2011). Panduan dan Aplikasi Pendidikan Karakter. Bandung: Yrama Widya.

Ardahan, F. (2012). Comparison of the new ecological paradigm (NEP) scale's level of participants and non-participants of outdoor sports with respect to some demographic variables: Turkey case. TOJRAS: The Online Journal of Recreation and Sport, 1(2), 8-18.

Ardianti, S. D., Wanabuliandari, S., \& Rahardjo, S. (2017). Peningkatan Perilaku Peduli Lingkungan dan Tanggung Jawab Siswa melalui Model EJAS dengan Pendekatan Science Edutainment. Jurnal Ilmiah "PENDIDIKAN DASAR," 4(1), 1-7. https://doi.org/10.30659/pendas.4.1.1-7

Ashar, J. (2018). Comparative Study of the Result of Environment Studying At Class Xi Sma At Adiwiyata School and Non. Jurnal Nalar Pendidikan, 6(1), 1-6.

Direktorat Jenderal Perlindungan Hutan dan Konservasi Alam. (2006). Pedoman Pembinaan Kelompok Pecinta Alam. Bogor: Departemen Kehutanan.

Ernawati, E., Azrai, E. P., \& Wibowo, S. S. (2016). Hubungan Persepsi Kearifan Lokal Dengan Sikap Konservasi Masyarakat Desa Lencoh Kecamatan Selo Di Taman Nasional Gunung Merapi. Biosfer: Jurnal Pendidikan Biologi, 9(1), 65-69. https://doi.org/10.21009/biosferjpb.9-1.10

Gusti, A., Isyandi, B., Bahri, S., \& Afandi, D. (2015). Hubungan Pengetahuan, Sikap dan Intensi Perilaku Pengelolaan Sampah Berkelanjutan Pada Siswa Sekolah Dasar di Kota Padang. Dinamika Lingkungan Indonesia, 2(2), 100-107. https://doi.org/10.31258/dli.2.2.p.100-107

Hines, J. M., Hungerford, H. R., \& Tomera, A. N. (1987). Analysis and synthesis of research on responsible environmental behavior: A metaanalysis. Journal of Environmental Education, $\quad 18(2), \quad 1-8$. https://doi.org/10.1080/00958964.1987.9943 482

Hudha, A. M., Husamah, \& Rahardjanto, A. (2019). Etika ingkungan (Teori dan Praktik Pembelajarannya). Malang: Penerbit Universitas Muhammadiyah Malang.

Kahfi, A. (2017). Tinjauan Terhadap Pengelolaan 
Quagga: Jurnal Pendidikan dan Biologi

Volume 12, Nomor 2, Juli 2020, pp.94-103

Sampah. Jurisprudentie, 4(1), 12-25. https://doi.org/10.24252/jurisprudentie.v4i1.3 661

Kaiser, F. G., Hübner, G., \& Bogner, F. X. (2005). Contrasting the theory of planned behavior with the value-belief-norm model in explaining conservation behavior. Journal of Applied Social Psychology, 35(10), 2150$2170 . \quad$ https://doi.org/10.1111/j.15591816.2005.tb02213.x

Kaplan, S. (2000). New Ways to Promote Proenvironmental Behavior: Human Nature and Environmentally Responsible Behavior. Journal of Social Issues, 56(3), 491-508. https://doi.org/10.1111/0022-4537.00180

Keraf, A. S. (2010). Etika Lingkungan. Jakarta: Penerbit Buku Kompas.

Mardianto, A., Koentjoro, \& Purnamaningsih, H. E. (2000). Penggunaan Manajemen Konflik Ditinjau dari Status Keikutsertaan dalam Mengikuti Kegiatan Pecinta Alam di Universitas Gadjah Mada Yogyakarta. Psikologi, 4(2), 111-119. Retrieved from https://jurnal.ugm.ac.id/jpsi/article/view/7003

Mulyana, R. (2009). Penanaman Etika Lingkungan Melalui Sekolah Perduli Dan Berbudaya Lingkungan. Jurnal Tabularasa PPS Unimed, 6(2), 175-180.

Nurhayati, Sukandar, P., \& Suryanda, A. (2014). The Comparison of Junior High School Student Comprehension about Slow Loris Conservation Based on Participation on Slow Loris Awareness Activity. Biosfer: Jurnal Pendidikan Biologi, VII(1), 49-57. https://doi.org/https://doi.org/10.21009/biosfe rjpb.7-1

Pasaribu, S. E. (2017). Jurnal Administrasi Publik Partisipasi Kelompok Pecinta Alam Forester Tapanuli Bagian Selatan dalam Pelestarian Orangutan Sumatera Participation of Nature Lovers Group of South Forester Tapanuli in Sumatran Orangutan Conservation Negara Indonesia memiliki. Jurnal Administrasi Publik, 7(2), 136-157.

Putra, R. A., \& Sari, G. G. (2017). Konsep Diri Anggota Mahasiswa Pecinta Alam FISIP Universitas RIAU. JOM FISIP, 4(2), 1-12.

Rifki, A. W., \& Listyaningsih. (2017). Hubungan Kegiatan Ekstrakulikuler Pecinta Alam dengan Sikap Peduli Lingkungan Siswa di
p-ISSN 1907-3089, e-ISSN2651-5869

https://journal.uniku.ac.id/index.php/quagga

SMK Negeri 2 BOJONEGORO. Kajian Moral Dan Kewarganegaraan, 05(20), 426440.

Rusdina, A. (2015). Membumikan Etika Lingkungan Bagi Upaya Membudayakan Pengelolaan Lingkungan yang Bertanggung Jawab. Istek, 9(2), 244-263.

Saputra, H., Febriana, S. K. T., \& Akbar, S. N. (2017). Pengaruh Peran Kepemimpinan Terhadap Perilaku Pro-Lingkungan Pada Anggota Organisasi Mahasiswa Pecinta Alam (Mapala) Piranha. Jurnal Ecopsy, 3(3), 155159.

https://doi.org/10.20527/ecopsy.v3i3.2667

Sigit, D.V., Miarsyah, M., Komala, R., Suryanda, A., Fadrikal, R., \& Ichsan, I. Z. (2019). Improvement of knowledge and attitude in conservation of mangrove and coral reefs through environmental education community network model. Journal of Physics: Conference Series, 1317(1). https://doi.org/10.1088/17426596/1317/1/012201

Sigit, Diana Vivanti, Azrai, E. P., Suryanda, A., \& Ichsan, I. Z. (2020). Analysis ProEnvironmental Behavior for Develop Digital Technology of Climate Change Book Serial in Environmental Learning. International Journal of Advanced Science and Technology, 29(5), 6254-6264.

Sudradjat, H. R. (2007). Mengelola Sampah Kota. Bogor: Penebar Swadaya.

Sukmana, T. (2011). Menjadi Pecinta Alam. Depok: Raih Asa Sukses.

Suryanda, A., Azrai, E. P., \& Wari, N. (2018). Pengaruh Penerapan Model Pembelajaran Group Investigation (Gi) Terhadap Kemampuan Berpikir Analisis Siswa Pada Materi Pencemaran Lingkungan. Biosfer: Jurnal Pendidikan Biologi, 9(2), 37-44. https://doi.org/10.21009/biosferjpb.9-2.6

Suryanda, A., Komala, R., \& Rahmawati, S. (2017). Sikap Masyarakat Di Desa Batu Busuk, Sumatera Barat Terhadap Konservasi Harimau Sumatera (Panthera Tigris Sumatrae) Berdasarkan Pengetahuannya. Biosfer: Jurnal Pendidikan Biologi, 10(2), 73-81.

https://doi.org/10.21009/biosferjpb.10-2.9

Thobroni, M., \& Mustofa, A. (2011). Belajar \& 
pembelajaran: pengembangan wacana dan praktik pembelajaran dalam pembangunan nasional. Yogyakarta: Ar-Ruzz Media.

Wulandari, R. (2016). Metode Kunjungan Lapangan untuk Menanamkan Kepedulian Terhadap Lingkungan Hidup. PEDAGOGIA: Jurnal Pendidikan, 5(1), 67-80. https://doi.org/10.21070/pedagogia.v5i1.90

Zelezny, L. C., \& Schultz, P. W. (2000). Promoting Environmentalism. Journal of Social Issues, 56(3), 365-371. https://doi.org/10.1111/00224537.00172

Zsóka, Á., Szerényi, Z. M., Széchy, A., \& Kocsis, T. (2013). Greening due to environmental education? Environmental knowledge, attitudes, consumer behavior and everyday pro-environmental activities of Hungarian high school and university students. Journal of Cleaner Production, 48, 126-138. https://doi.org/10.1016/j.jclepro.2012.11.030 